\title{
Bioactivity assay of extracts from Calocedrus macrolepis var. formosana bark
}

\author{
Louis Kuoping Chao ${ }^{\text {a }}$, Kuo-Feng Hua ${ }^{b}$, Hsien-Yeh Hsu ${ }^{b}$, \\ Yu-Chang Su ${ }^{\mathrm{c}}$, Shang-Tzen Chang ${ }^{\mathrm{d}, *}$ \\ ${ }^{a}$ Department of Biological Science and Technology, Chung Hwa College of Medical Technology, Tainan 717, Taiwan \\ ${ }^{\mathrm{b}}$ Faculty of Biotechnology and Laboratory Science in Medicine, Institute of Biotechnology in Medicine, National Yang-Ming University, Taipei 112, Taiwan \\ ${ }^{\mathrm{c}}$ Division of Wood Cellulose, Taiwan Forestry Research Institute, Taipei 100, Taiwan \\ ${ }^{\mathrm{d}}$ School of Forestry and Resource Conservation, National Taiwan University, Taipei 106, Taiwan
}

Received 21 June 2005; received in revised form 17 October 2005; accepted 23 October 2005

Available online 15 December 2005

\begin{abstract}
Alcoholic extracts from bark of Calocedrus macrolepis var. formosana Florin (Cupressaceae) were extracted successively using $n$-hexane, dichloromethane, ethyl acetate, 1-butanol and water, which gave $34.8 \%, 34.1 \%, 24.1 \%, 3.3 \%$ and $3.7 \%$ soluble fractions, respectively. Antioxidation activity of these fractions by DPPH assay and dissimilar $\mathrm{IC}_{50}$ values of the DPPH showed that ethyl acetate fraction had the best antioxidant activity; its $\mathrm{IC}_{50}$ was $2.6 \mu \mathrm{g} / \mathrm{ml}$. Analyses of the composition and anti-inflammatory activity of the subfractions from $n-\mathrm{C}_{6} \mathrm{H}_{14}$ fraction showed that the T3 and $\mathrm{H}_{\text {ppt }}$ had the best anti-inflammatory activity in LPS-stimulated murine macrophage $\mathrm{J} 774 \mathrm{~A}$. 1 cells, respectively; moreover, their major constituent was sugiol (T3 37.1\%, H5 ppt 81.1\%), which at dosages of $10 \mu \mathrm{g} / \mathrm{ml}$ inhibited proIL-1 $\beta$ protein production completely. Furthermore, the T1 also exhibited anti-inflammatory activity, and its major constituent was ferruginol (above $85.6 \%$ ).
\end{abstract}

(c) 2005 Elsevier Ltd. All rights reserved.

Keywords: Calocedrus macrolepis var. formosana; Extracts; Antioxidant activity; Anti-inflammatory capacity

\section{Introduction}

Lipopolysaccharide (LPS) is the major wall component of Gram-negative bacteria (Raetz and Whitfield, 2002), which is able to activate monocytes/macrophages to secrete various inflammatory cytokines. Interleukin-1 beta (IL-1 $\beta$ ) is one of the major mediators of inflammatory response mainly secreted from LPS-stimulated macrophages (Hsu and Wen, 2002; Wang et al., 2003). The Calocedrus macrolepis var. formosana Florin (Cupressaceae) is a native tree that grows at elevations of $800-1500 \mathrm{~m}$ in Taiwan's central mountains, whose bark is always discarded in the forestry industry. In addition, the bark of C. macrolepis var. formo-

\footnotetext{
* Corresponding author. Tel.: +8862 33664626; fax: +886223654520.

E-mail address: peter@ntu.edu.tw (S.-T. Chang).
}

sana has been the prevailing folklore medication in Taiwan's countryside in the past. Our recent research demonstrated that alcoholic extracts from C. macrolepis var. formosana exhibited a significant inhibitory activity against the DPPH radical (Wang et al., 2004). To further explore its potential as a source of natural drugs, the purpose of this study was to investigate the effective composition and anti-inflammatory capacity of the alcoholic extracts from barks of C. macrolepis var. formosana by using a murine macrophage model (J774A. 1 cell).

\section{Methods}

\subsection{Extraction and fractionation}

The samples of C. macrolepis var. formosana were collected in September 2003 from the Lien Hua-Chin 
Research Center located in Nantou County in central Taiwan. The species was identified and voucher specimens were deposited at the laboratory of wood chemistry (School of Forestry and Resource Conservation, National Taiwan University). Barks of C. macrolepis var. formosana $(10 \mathrm{~kg}$ d.w. $)$ were extracted with ethanol $(95 \% \mathrm{v} / \mathrm{v}$, $10 \mathrm{~d}$ repeated 3 times) at room temperature. The extracts were concentrated to get alcoholic extracts (AE) approximately $410 \mathrm{~g}$. AE $(205 \mathrm{~g})$ was successively extracted with $n$ hexane $\left(n-\mathrm{C}_{6} \mathrm{H}_{14}\right)$, dichloromethane $\left(\mathrm{CH}_{2} \mathrm{Cl}_{2}\right)$, ethyl acetate (EtOAc), 1-butanol $(\mathrm{BuOH})$, and water $\left(\mathrm{H}_{2} \mathrm{O}\right)$. The $n$-hexane fraction was applied on the top of a $160 \mathrm{~g}$ silica gel column. The column was eluted with $n-\mathrm{C}_{6} \mathrm{H}_{14} /$ EtOAc from 95/ 5 to $0 / 100$, followed by eluting with EtOAc/alcohol from $100 / 0$ to $0 / 100$. Each eluted volume of subfraction was $1000 \mathrm{ml}$, except that $\mathrm{H} 1$ subfraction was $4000 \mathrm{ml}$. The collected subfractions were then dried. The water-soluble alcoholic extracts (WAE) fraction was extracted directly from AE using only $\mathrm{H}_{2} \mathrm{O}$.

\subsection{DPPH (1,1-diphenyl-2-picrylhydrazyl) assay}

The scavenging action of DPPH free radicals using different fractions of C. macrolepis var. formosana alcoholic extracts was measured according to the method of Wang et al. (2004). The inhibition ratio (\%) was calculated using the following equation: $\%$ inhibition $=[$ (absorbance of control-absorbance of test sample)/absorbance of control] $\times 100$.

\subsection{Gas chromatography-mass spectrometry (GC-MS) analysis}

All of the different samples from extracts and separated fractions were performed by GC-MS (HP 6890N, with MS detector model HP 5973) and equipped with a DB-5HT column $(15 \mathrm{~m}$ in length, $0.25 \mathrm{~mm}$ i.d., $0.1 \mu \mathrm{m})$. The oven temperature was increased from 85 to $300^{\circ} \mathrm{C}$ at a rate of $10^{\circ} \mathrm{C} /$ min. The injection temperature was $300^{\circ} \mathrm{C}$, detector temperature was $280^{\circ} \mathrm{C}$ and helium was used as a carrier gas at a split ratio of 20:1. The compounds were identified by comparison of their mass spectrometric fragmentation patterns with those of authentic standards.

\subsection{Bioassay}

Murine macrophage J774A. 1 cell was obtained from ATCC (Rockville, MD), propagated in RPMI 1640

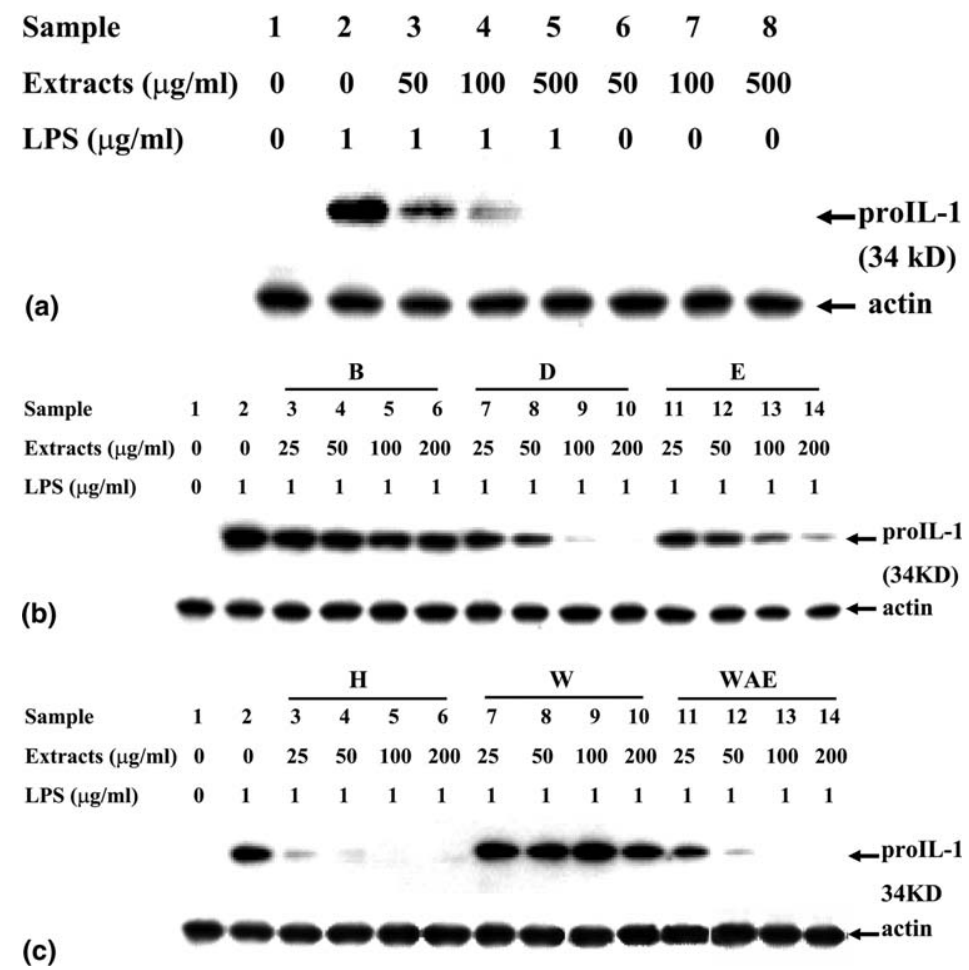

Fig. 1. Effects of alcoholic extracts from barks of $C$. macrolepis var. formosana on proIL-1 $\beta$ protein expression in LPS-stimulated J774A. 1 cells. Whole cell lysates were analyzed by Western blot using anti-IL-1 $\beta$ and anti-actin antibody. The proIL-1 $\beta$ and actin (as an internal control) are indicated as arrows on the right side. These experiments were repeated three times and a representative result is shown in the figure. (a) Cells were pretreated with indicated concentration of alcoholic extracts from barks of $C$. macrolepis var. formosana for $30 \mathrm{~min}$, followed by LPS ( $1 \mu \mathrm{g} / \mathrm{ml})$ or medium treatment for additional $6 \mathrm{~h}$. Sample 1 was the control and sample 2 was only treated with LPS. (b) Cells were pretreated with indicated concentration of extracts from different fractions (B, BuOH fraction; $\mathrm{D}, \mathrm{CH}_{2} \mathrm{Cl}_{2}$ fraction; E, EtOAc fraction) for $30 \mathrm{~min}$, followed by LPS $(1 \mu \mathrm{g} / \mathrm{ml})$ treatment for additional $6 \mathrm{~h}$. Sample $1 \mathrm{was}$ the control and sample 2 was only treated with LPS. (c) Cells were pretreated with indicated concentration of extracts from different fractions $\left(\mathrm{H}, n\right.$ - $\mathrm{C}_{6} \mathrm{H}_{14}$ fraction; $\mathrm{W}, \mathrm{H}_{2} \mathrm{O}$ fraction; WAE, WAE fraction) for $30 \mathrm{~min}$, followed by LPS $(1 \mu \mathrm{g} / \mathrm{ml})$ treatment for additional $6 \mathrm{~h}$. Sample $1 \mathrm{was}$ the control and sample 2 was only treated with LPS. 
medium supplemented with $10 \%$ heat-inactivated fetal bovine serum (Hyclone Co., Logan, UT) and $2 \mathrm{mM} \mathrm{L-gluta-}$ mine (Life Technologies, Inc., MD) and cultured in a $37^{\circ} \mathrm{C}$, $5 \% \mathrm{CO}_{2}$ incubator, unless otherwise indicated. J774A. 1 cells were pretreated with extracts (dissolved in DMSO) for $30 \mathrm{~min}$, followed by LPS $(1 \mu \mathrm{g} / \mathrm{ml})$ treatment for additional $6 \mathrm{~h}$. ProIL-1 $\beta$ protein expression level was analyzed by Western blot using anti-IL-1 $\beta$ antibody as described by Hsu et al. (2001).

\subsection{Statistical analysis}

Statistical differences between the experimental groups were examined by analysis of variance, and statistical significance was determined at $p<0.05$. The experiments were conducted three times or as indicated and all data are expressed as mean $\pm \mathrm{SD}$.

\section{Results and discussion}

\subsection{Yields of fractions and antioxidant activity}

The $n-\mathrm{C}_{6} \mathrm{H}_{14}$ soluble fraction showed the highest yields (about 34.8\%) and the next were the $\mathrm{CH}_{2} \mathrm{Cl}_{2}$ fraction $34.1 \%$, EtOAc fraction $24.3 \%, \mathrm{H}_{2} \mathrm{O}$ fraction $3.7 \%$ and $n$ $\mathrm{BuOH}$ fraction $3.1 \%$. The results of DPPH assay revealed EtOAc fraction had the best inhibitory activity against the DPPH radical, with an $\mathrm{IC}_{50}$ value of $2.6 \mu \mathrm{g} / \mathrm{ml}$. This value was 9-fold higher than the $25 \mu \mathrm{g} / \mathrm{ml}$ of alcoholic extracts of C. formosana in $\mathrm{IC}_{50}$ (Wang et al., 2004). The secondary $\mathrm{IC}_{50}$ value was $6.8 \mu \mathrm{g} / \mathrm{ml}$ from WAE fraction, and except for the $\mathrm{H}_{2} \mathrm{O}$ fraction, which showed the worst inhibitory activity at approximately $81.5 \mu \mathrm{g} / \mathrm{ml}$, the others were between 15 and $17 \mu \mathrm{g} / \mathrm{ml}$.

\subsection{Anti-inflammatory activity of different fractions}

Fig. 1a shows that a dosage of $50 \mu \mathrm{g} / \mathrm{ml}$ of the alcoholic extract (AE) from C. macrolepis var. formosana markedly inhibited proIL-1 $\beta$ protein expression in LPS-stimulated J774A. 1 cells (sample 3). At $100 \mu \mathrm{g} / \mathrm{ml}$ dose, approximately $95 \%$ of proIL-1 $\beta$ protein expression was inhibited (sample 4). AE did not stimulate the inflammatory cytokine proIL$1 \beta$ in J774A. 1 cells (samples $6-8$ ). Fig. $1 \mathrm{~b}$ showed that the anti-inflammatory bioactivity of $\mathrm{BuOH}$ fraction (samples 3-6) and $\mathrm{CH}_{2} \mathrm{Cl}_{2}$ fraction (samples 7-10) were worse at different dosages for the J774A. 1 cells. Interestingly, the EtOAc fraction had the best antioxidant activity against DPPH in this study, but the anti-inflammatory bioactivity was not primarily effective. The $n-\mathrm{C}_{6} \mathrm{H}_{14}$ fraction (Fig. 1c, samples 3-6) at a low dosage of $25 \mu \mathrm{g} / \mathrm{ml}$ restrained $95 \%$ of proIL-1 $\beta$ protein expression (Fig. 1c). Both the anti-inflammatory ability and the antioxidant activity of the $\mathrm{H}_{2} \mathrm{O}$ fraction were low (samples 7-10). At a dosage of $50 \mu \mathrm{g} / \mathrm{ml}$, the anti-inflammatory ability of the WAE fraction could inhibit $98 \%$ of proIL-1 $\beta$ protein expression (Fig. 1c, samples 11-14), indicating that its efficacy was only slightly lower than that of the $n-\mathrm{C}_{6} \mathrm{H}_{14}$ fraction.

Fig. 2a demonstrated that T3 (the mixture of subfractions $\mathrm{H} 5$ and $\mathrm{H} 6$ ) and $\mathrm{H} 5_{\mathrm{ppt}}$ (the precipitant from subfraction $\mathrm{H} 5$ when it was concentrated) had the best anti-inflammatory capacity, respectively. At a dosage of $10 \mu \mathrm{g} / \mathrm{ml}$, they inhibited

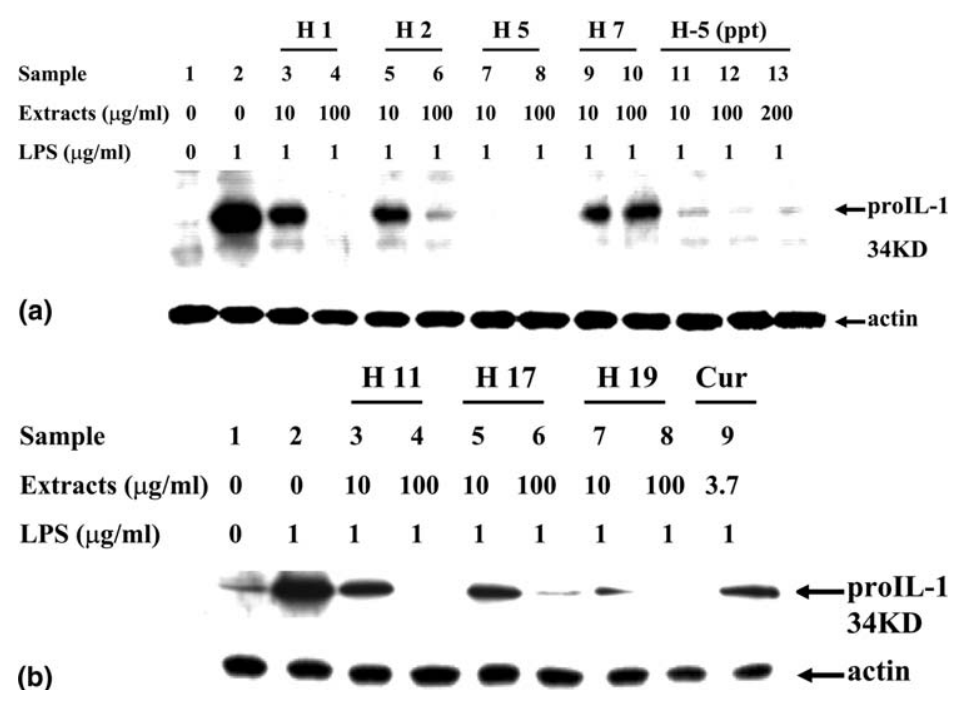

Fig. 2. Effects of subfractions from the $n-\mathrm{C}_{6} \mathrm{H}_{14}$ fraction on intracellular pro-IL-1 $\beta$ in LPS-stimulated J774A. 1 cells. The cells were pretreated with 10 and $100 \mu \mathrm{g} / \mathrm{ml}$ of different subfractions of hexane fraction for $30 \mathrm{~min}$, respectively, followed by LPS $(1 \mu \mathrm{g} / \mathrm{ml})$ treatment for an additional $6 \mathrm{~h}$. (a) Sample $1 \mathrm{was}$ the control and sample 2 was only treated with LPS. The T1 sample contained only H1 subfraction, T2 was the mixture of subfractions H2, H3 and H4. T3 was the mixture of subfractions $\mathrm{H} 5$ and $\mathrm{H} 6$. T4 was the mixture of subfractions $\mathrm{H} 7, \mathrm{H} 8, \mathrm{H} 9$ and $\mathrm{H} 10$. The $\mathrm{H} 5$ ppt was the precipitant from subfraction $\mathrm{H} 5$ when it was concentrated. (b) Sample 1 was the control and sample 2 was only treated with LPS. T5 was the mixture of subfractions H11, H12, H13, H14, $\mathrm{H} 15$ and H16. T6 was the mixture of subfractions H17 and H18. T7 was the mixture of subfractions H19, H20, H21 and H22. Curcumin (3.7 $\mu$ g/ml) was used as a positive control. Whole cell lysates were analyzed by Western blot using anti-IL-1 $\beta$ and anti-actin antibody. The proIL-1 $\beta$ and actin (as an internal control) are indicated as arrows on the right side. 
all proIL-1 $\beta$ protein expression (Fig. 2a, samples 7 and 8 , and 11-13). Next, T7 and T1 separately, at a dosage of $100 \mu \mathrm{g} / \mathrm{ml}$ completely inhibited proIL-1 $\beta$ protein expression (Fig. 2b, samples 7 and 8).

\subsection{Chemical composition of bioactive subfractions}

By using GC-MS, it was found that the major constituent of T3 was sugiol (37.1\%). Moreover, $\mathrm{H} 5_{\mathrm{ppt}}$ contained $81.1 \%$ sugiol. Similar result was obtained in the WAE fraction, which had $39.3 \%$ sugiol, and it was also accompanied by a good inhibitory effect on LPS-induced proIL-1 $\beta$ protein expression. The major constituent of T1 was ferruginol $(85.6 \%)$, which had fine anti-inflammatory activity.

\section{Conclusion}

Results demonstrated that a low dosage of $10 \mu \mathrm{g} / \mathrm{ml}$ of $\mathrm{H} 5_{\text {ppt }}$ from C. macrolepis var. formosana completely inhibited proIL-1 $\beta$ protein expression in LPS-stimulated macrophages. Its major constituent was sugiol (contains $81.1 \%$ ). This is the first report to demonstrate that alcoholic extracts of C. macrolepis var. formosana bark have an anti-inflammatory activity in macrophages. However, the efficacy and safety of these compounds needs to be further investigated, if it is to be used as a source of natural drugs in the future.

\section{Acknowledgements}

This study was supported by a grant (NSC-92-2313-B002-042) from the National Science Council of Taiwan.

\section{References}

Hsu, H.Y., Wen, M.H., 2002. Lipopolysaccharide-mediated reactive oxygen species and signal transduction in the regulation of interleukin-1 gene expression. J. Biol. Chem. 277, 22131-22139.

Hsu, H.Y., Chiu, S.L., Wen, M.H., Chen, K.Y., Hua, K.F., 2001. Ligands of macrophage scavenger receptor induce cytokine expression via differential modulation of protein kinase signaling pathways. J. Biol. Chem. 276, 28719-28730.

Raetz, C.R.H., Whitfield, C., 2002. Lipolysaccharide endotoxins. Annu. Rev. Biochem. 71, 635-700.

Wang, J.H., Majella Doyle, M., Manning, B.J., Blankson, S., Wu, Q.D., Power, C., Cahill, R., Redmond, H.P., 2003. Cutting Edge: Bacterial lipoprotein induces endotoxin-independent tolerance to septic shock. J. Immunol. 170, 14-18.

Wang, S.Y., Wu, J.H., Cheng, S.S., Lo, C.P., Chang, H.N., Shyur, L.F., Chang, S.T., 2004. Antioxidant activity of extracts from Calocedrus macrolepis var. formosana leaf, bark and heartwood. J. Wood Sci. 50, 422-426. 